\title{
Research on the Major Factors that Influence the Consumer Psychology in the Marketing Process
}

\author{
Yan Zhang \\ EC. Institute ,Jiu Jiang University, \\ Jiujiang,Jiangxi, 332005 China
}

\begin{abstract}
In this paper, we conduct research on major factors that influence the consumer psychology in marketing process. In marketing system, customer relationship management mainly summarized as: the purpose of the enterprise with the high quality products, fast and perfect service to attract new customers, maintain the good relationship between good and old customers. Many enterprises in the market in China in the process of economic transition has begun to attach importance to marketing strategic planning, but truly strategic decision making and planning is one of the few. Most enterprise pays attention to raise the level of the sales growth and profits in the eye of little concern for the future market of possession and the actual position in the market. Under this background, we propose the consumer psychology related research in this paper for enhancement.
\end{abstract}

Keywords- Major Factors, Consumer Psychology, Marketing Process, Influence, Review.

\section{Introduction}

Traditional enterprise marketing strategy point of view of the enterprise marketing activities as a pure sales approach that is to help enterprises to expand the market sales channels, transfer the products to consumers in the hands of a support activity, the traditional view consumer forever pursue cheap and fine products, for the style of the product, packaging, additional services, cultural connotation and the extension of other things is far from the price is more important, therefore, their work is focused on at a relatively low cost of production to produce more products. Under the basic background of the new economy has a traditional economy the economic situation and general characteristics of the objective requirements for the enterprise marketing activities under the new situation from essentially different from the traditional marketing activities and scenarios [1-3].

The research object of marketing is to meet consumer demand as the center of enterprise marketing activities process and its regularity, namely in the specific market environment, that enterprises on the basis of market research, in order to meet the need of real and potential consumers and users that can be separated into the listed aspects. (1) Marketing has a strong social practice. Basic principle, method and strategy of marketing to the general enterprise marketing activities has a guiding significance and practical value that is effective to guide enterprises to adapt to the changing practice guidelines for the target market, it focuses on a buyer's market under the condition of the seller's marketing management problems. (2) Marketing research scope, expands unceasingly that in practice has been breached, and circulation of commodities domain to production in the field of prenatal activity, including market research, product design, etc. (3) Marketing constitute an important content of management, it should fully use the research achievements of multiple disciplines, to analyze the marketing environment, consumer psychology and consumer behavior. Both to do qualitative analysis that also need to make quantitative analysis. (4) Macro marketing is a kind of social and economic activities, its purpose is to through some social marketing system, guide a certain economic goods from producers to consumers 
and users, meet the needs of the society and achieve the general goal of society [4-5].

Consumer is the key to the survival of the enterprise, better service to consumers is fundamental to sustained development of enterprises. In some extent, the competition between the enterprises is the competition for general customer resources. Companies to win customers, gain a unique competitive advantage, in addition to providing the high quality products which also should pay attention to the psychological contract between building and consumers. Expectations, in the psychological contract is expected and look forward to each other will satisfy their needs of certain as want to show that hope that kind of behavior. These expectations have no written expression which needs each other to look carefully, elusive, estimates, and understanding and if the other party fails to comprehend expectation, does not meet their requirements is changed the about, destroyed a psychological contract.

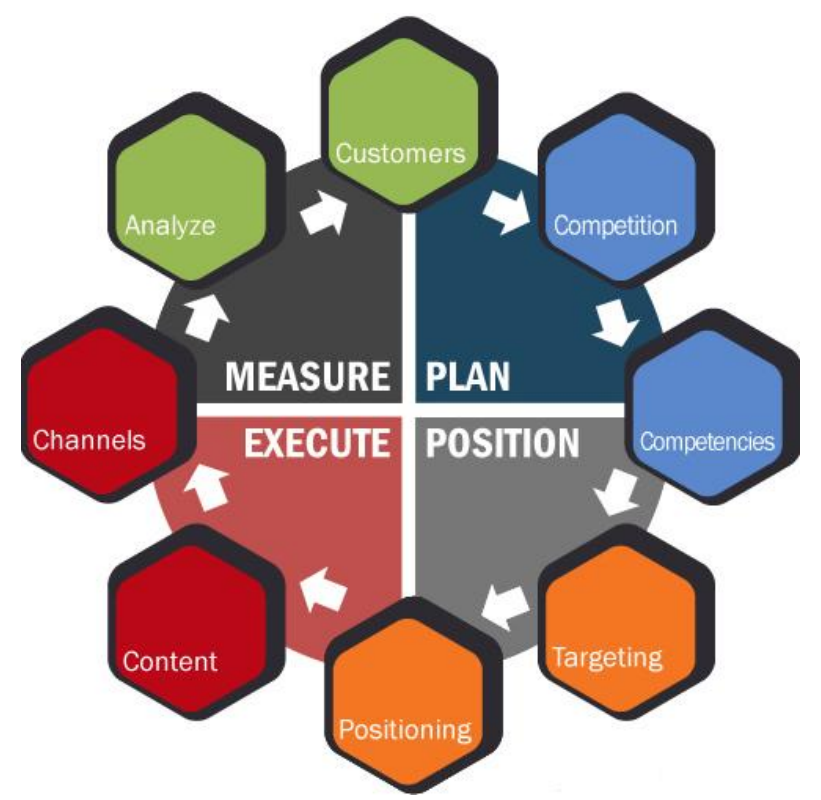

Figure 1. The General Procedures of the Marketing Process

In this paper, we conduct research on the major factors that influence the consumer psychology in the marketing process. Consumer behavior is the foundation of marketing, and also is the key to solve the problem of the marketing practice, but also occupy the market enterprise to enter the market and develop its own key. Paper introduces the present situation of consumer behavior theory as this paper analyzes the consumer's psychological factors and the relationship between these factors. In following sections, we will introduce our novel perspectives in detail.

\section{The Proposed Methodology}

The Customer and Market. Customer and customer relationship in fundamental changes have taken place in the status and role of enterprise management has been raised to an unprecedented height, to promote the enterprises to change the way of new competition, such as general customer relationship management in practice. In the process, to discuss the value of customers is becoming more and more attention. Today, although no matter in which industry, enterprise degree is more and more high to the attention of the customer relationship, take the customer as the center of marketing and management idea is accepted by more and more enterprises [6].

In marketing system, customer relationship management mainly summarized as: the purpose of the enterprise with the high quality products, fast and perfect service to attract new customers, 
maintain the good relationship between good and old customers; Optimize the business process of enterprise marketing, lower costs, needed to obtain and maintain customer realize the ascension of the customer delivered value that improve customer satisfaction and the loyalty to the enterprise and product, the enhancement enterprise centripetal force and cohesive. From this standpoint, this paper determined taking enterprise as the main body of analysis perspective with the definition of customer value and customer relationship value. That direction is defined as the value of general customers is enterprise creates value for customers, its beneficiaries and the owner is a customer, after it is created by the enterprise to the customer as the customer relationship value is to show the enterprise in the process of the customer relationship management and management pursues and returns. Customer relationship management system in enterprise marketing role can be organized as the follows.

- Attract customers improve the level of corporate profits. Marketing management in the work can make full use of customer relationship management system to attract a customer group, aiming at the characteristics of different customers to develop different marketing solutions, but also can combine the local culture to increase the target customers to win better market.

- Use of advanced technology to expand enterprise marketing. After the customer relationship management system need to have relevant staff to maintain it, especially in the development of modern network technology, management personnel should make full use of advanced technology to expand the enterprise marketing, this can better ensure the development.

- Make use of the data to reduce the risk of enterprise market marketing. Customer relationship management system is mainly to solve communication, communication between businesses and their customers, the way of communication to build on the basis of mutual trust, only in this way can reduce the enterprise marketing risk, win more profit for the enterprise.

Enterprise in the marketing activities have switched from traditional product as the core to take the customer as the center of the operation mode, in implementation of take the customer as the center of the operation mode as the enterprise should adopt a more modern customer relationship management system, a reasonable adjustment and optimization of enterprise organization structure for enterprise customer relationship management in the marketing contribution more energy. The customer resource of enterprise is divided into several types according to the important degree, according to different customers make detailed customer management and the service which make the enterprise customer relationship management focusing, improve the quality of service, save administrative costs, improve customer relationship management efficiency, better make enterprise in the fierce market marketing to realize the economic benefit of ascension [7].

The Principles of the Marketing Process. From the perspective of the application of marketing, marketing focuses on selling the meticulous planning, the market before the market planning is the key to the success of accurate source of information and processing of information science. Statistics as a science of gathering information, processing information that just can in all aspects of marketing planning stage in the market play a key role in scientific decision.

Marketing is the focus of the academic work in our country, that how to push marketing work to in-depth, put in place, to carry out basic detailed, how the modern marketing concept and marketing strategy to carry out the marketing practice, how to help a specific market segment 
corporate research, develop and implement a system of practical and competitive marketing strategy.

- Marketing knowledge. Pay attention to spread to the public on the new science and technology and their influence on people's life, by popular science propaganda, let the consumer not only learning, and know the why, to establish new product concept, which make basic consumers germinate the need for new products and expand the market.

- Personalized marketing. The enterprise release the attention to person, a person's personality and personality to meet demand on an unprecedented center position, with enterprise and the market gradually establish a new type of relationship, establish the database and information files, individual consumers and consumers to establish a more personal contact, understand market trends and customer needs in a timely manner, to provide sales and service.

- Chain business channel. The vertical marketing system is a kind of vertical development, is by the producers, wholesalers and retailers form the unity of the consortium, it apply the principle of modern industrial production to business management.

- Integrated marketing communication. This is a marketing communications plan concept, that namely in the plan for different forms of the communication, such as the general advertising, direct response advertising, sales promotion, public relations and so on make an estimate of the strategic position [8].

For domestic enterprises, by means of scientific and effective marketing strategy to the enterprise product sales go out is the most basic goal, if there is a mistake in marketing strategy formulation, tend to cause a large number of hoarding products, which hinder the healthy development of the enterprise to a great extent. At the same time, in the process of the marketing strategy choice must be aimed at analyzing the market, accurately grasp the actual market demand, further study of related information data, only in this way can choose the most reasonable and scientific marketing strategy, this also is for market research of the value of the effective feedback and market research to provide basic accurate reference for the future. The stable and healthy development of modern enterprises cannot do without scientific and effective marketing strategy that should actively absorb and draw the lessons from the successful experience of advanced enterprises at home and abroad, to help in their own development on the road to go further. The following figure 2 demonstrates the principles. 


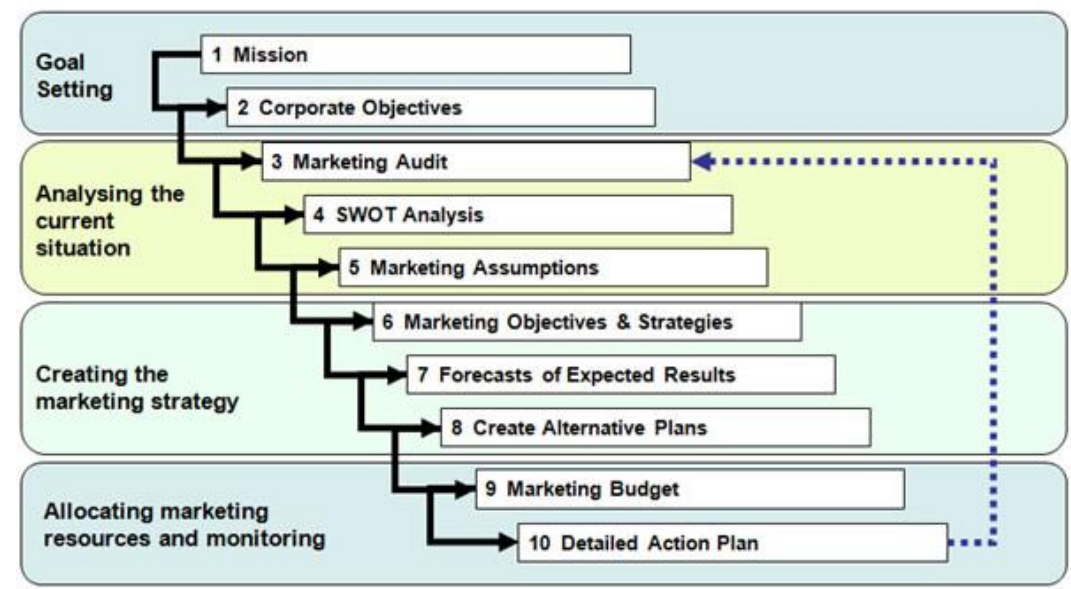

Figure 2. The Marketing Plan and Operation Steps

The Consumer Psychology. Individual consumer psychology is the main factors including the general personality, lifestyle, and self-concept. Personality refers to the decisions and refraction how individuals respond to environmental intrinsic psychological characteristics. According to definition of scholars, individual personality can be in person to yourself and all things in the environment to adapt to shows different from those of other people's personality, systemically and the durability. The definition of a lifestyle has broad sense and narrow sense, personality, lifestyle, and the relationship between self-concept in the consumer behavior research, often from the influence factors of consumer behavior, discussed under the influence of various factors of consumer purchase decision rule.

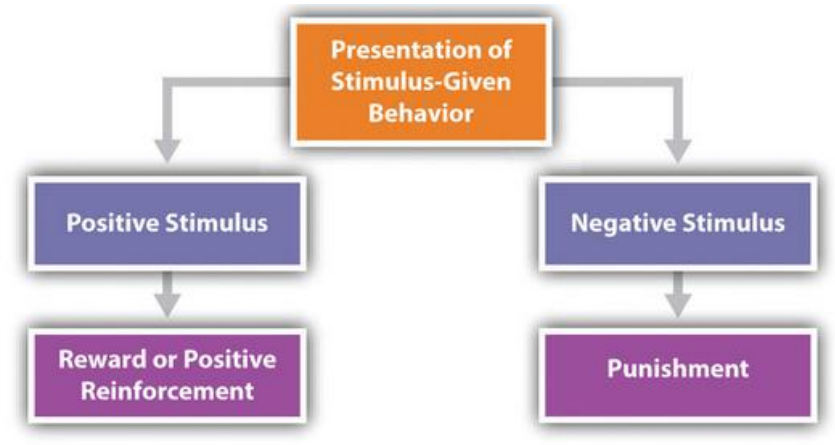

Figure 3. The Demonstration of the Consumer Psychology

From international and domestic market marketing the deductive process of it is not hard to see such a reason, under the condition of market economy, enterprises in the process of marketing focus and the difficulty is how to carry on the emotional communication with customers, financing, make consumer understanding of enterprises and products, identification, to find a solution to the enterprise with consumer understanding of this point. That is to say, communication emotion is more important than selling products, to create consumer is more important than developing products.

Less because of the psychological contract in the field of the marketing research, at present many enterprises inadequate understanding of psychological contract even there is some misunderstanding. (1) Think the psychological contract will only increase the cost of enterprise, conflicts with the nature of corporate profits. These companies will instinctively avoid psychological contract. (2) High expectations of the psychological contract, the enterprise will start on psychological contract into the great enthusiasm, because of general psychological contract revenue delayed or temporary setbacks, enterprise of psychological contract skeptical. (3) Think the psychological contract is slick theory, there is no the possibility and value of practical operation and these companies will have a negative psychological contract rejection of psychology.

Companies to be successful, we need between products and consumers to build general 
effective communication bridge. Understand the consumer's perception of the product and purchase situation, must be in-depth analysis for the consumer, then take measures to meet the demand of consumers. First of all, through the analysis of the consumers for background information which carries on the preliminary classification and second, the different consumer groups and product, investigate what products can meet their needs, what is the motivation for buying products. Again, according to the self-concept and way of life to subdivide consumer groups, their access to information, cognition and attitude towards the product, the product can bring them what kind of satisfaction.

\section{Conclusion}

In this paper, we conduct research on the major factors that influence the consumer psychology in the marketing process. With the development of market economy, the demand of the consumer market has changed markedly. People have gradually realized that buy products not only need to meet their material needs, more need to satisfy their psychological need, that is to say, the use function of the consumer needs not only the product, also need the product of psychological functions. Enterprise's growth and dissolution is the general rule of evolution, this shouldn't make a fuss, but it is worth noting that the enterprises win or eliminated, the problem is not all on the product quality, as brand building and resources endowment, and is more of a change in consumer psychology, and marketing to adapt to changes in consumer psychology, follows a market changes over the psychology of basic consumer to win consumer companies will flourish and loss of enterprise of failure law of consumers. In the future, we will review more related issues for theoretical optimization.

\section{References}

[1] Toksarı, M., İ. İsen, and A. Dagc1. "A city branding and marketing process: an application in Konya." Academic Review of Economics and Administrative Sciences 7.1 (2014): 328-343.

[2] Richards, G. J., et al. "Evaluation of the microclimate in poultry transport module drawers during the marketing process of end-of-lay hens from farm to slaughter." Veterinary Record: Journal of the British Veterinary Association 171.19 (2012).

[3] Coleman, James E., and Kirk C. Heriot. "The use of social media by small businesses: A conceptual framework." Allied Academies International Conference. Academy of Marketing Studies. Proceedings. Vol. 18. No. 1. Jordan Whitney Enterprises, Inc, 2013.

[4] Webster, Geoffrey B., and Margee Hume. "Analysing the Role of Social Media in Dialogue Marketing and Management as a Contemporary Franchising Local Area Marketing Technique." Competitive Social Media Marketing Strategies (2016): 20.

[5] Facca-Miess, Tina M., and Nicholas JC Santos. "Fostering fair and sustainable marketing for social entrepreneurs in the context of subsistence marketplaces." Journal of Marketing Management 30.5-6 (2014): 501-518.

[6] Granot, Elad, Thomas G. Brashear, and Paulo Cesar Motta. "A structural guide to in-depth interviewing in business and industrial marketing research." Journal of Business \& Industrial Marketing 27.7 (2012): 547-553.

[7] Radwan, Hatem Radwan Ibrahim. "Evaluating the Effectiveness of Social Media as A Marketing Tool in The Hotel Sector: A Case Study on Four and Five Star Hotels in Makkah, Saudi Arabia." Journal of Faculty of Tourism and Hotels, Fayoum University 8.1 (2016).

[8] DiGuiseppi, Carolyn G., et al. "Church-based social marketing to motivate older adults to take balance classes for fall prevention: cluster randomized controlled trial." Preventive medicine 67 (2014): 75-81. 